\title{
Peculiarities of the Water Framework Directive implementation in the Canary Islands' superficial waters
}

\author{
I. Del Barrio, R. Álvarez, I. Santana, O. Briz, R. Bordón, \\ J. Hernández \& N. González \\ Canary Institute of Marine Sciences
}

\begin{abstract}
Nowadays, Directive 2000/60/CEE is the European Union's basic instrument to manage hydrologic resources in a sustainable way. Its main objectives are the progressive reduction of pollutant spills and the achievement of a good ecological quality of superficial waters. The first aspect requires registering all the spilled substances and controlling their concentration in water. In the Canary Islands, it is complicated to establish the substances to be analyzed since the inventory of pressures is not updated. Therefore, most of the very toxic compounds (Annex X) are in the Monitoring Program. Regarding the evaluation of ecological quality, biological indicators and their quality thresholds are being defined by the intercalibration exercise, which is organised among states that belong to the same ecoregion. The Canary Islands belong to the Northeast Atlantic Geographical Intercalibration Group. Although it is being attempted to consider each place's idiosyncrasy (Spain, Portugal, France, UK, Ireland, Belgium, Netherlands, Denmark, Norway and Sweden), the indicators proposed for the time being may not evaluate conveniently their ecological state, especially in the peripheral regions, such as the Canary Islands. This was not predicted by the Directive, which did not differentiate between the diverse Atlantic regions. Nevertheless, if these subjects come to a consensus, the European Union will be on its way to attain the protection of one of the most valuable resource in the near future: the water.
\end{abstract}

Keywords: Water Framework Directive, ecological quality, coastal waters. 


\section{Introduction}

The good state of the hydrological resources is the main target of any environmental policy. Its sustainability is an important concern at an international level. Therefore, since the 70's, the aquatic systems have been protected from many perspectives and at different levels. In particular, the marine and coastal waters have been the object of few management tools that in addition contemplate very different aspects. The European legislation has regulated the conservation of coastal waters using different types of normatives that did not consider the littoral as a whole, contemplating it by small sections: the bathing waters (Directive 76/160/CEE), the vulnerable areas due to agricultural origin nitrate contamination (Directive 91/676/CEE), and the sensible areas by euthrophication due to urban waste water pollution (Directive 91/271/CEE). Also, other legal texts regulated the spill of polluting substances, like Directive 76/464/CEE, Directive 86/280/CEE or Directive 96/61/CE, establishing threshold values in the spills or in the receiving environment. Finally, in order to avoid marine environment pollution on European citizen's tables, on October $30^{\text {th }}, 1979$ Directive 79/923/CEE was approved, establishing the quality of water needed for mollusc culture.

Due to the dispersion of existing legal texts, the task of managing the water efficiently was complicated. In addition, the increasing pressure that meant the continuous growth of good quality water demand, confirmed the need of taking measures to protect communitarian waters in qualitative terms. Thus, the European Union took a new preservation strategy for its hydrological resources elaborating Directive 2000/60/CE, by which a communitarian action frame in the scope of water policy is established (known as the Water Framework Directive, from now on WFD).

The WFD is at present time the basic protection tool of underground and superficial waters, including interior waters, those of transition (estuaries) and coasts. It delegates the competence on hydrological management to the hydrographic demarcations, defined according to the existing hydrologic basins (in which the adjacent coastal waters are included). It arises as a unification instrument in order to incorporate in a single document what is found in all related to the matter. Article 4 collects the main objectives to be achieved after its application. The most important are:

i) To prevent deterioration, protect and improve the state of the aquatic resources.

ii) To promote sustainable uses of water.

iii) To protect and improve the aquatic environment, using specific measures to obtain the progressive reduction of spills.

iv) To assure the progressive reduction of underground water pollution.

v) To contribute to mitigate the effects of floods and droughts.

Finally, it aims to assure a sustainable management of the water and to reach a good quality of the water in 2015 [1]. Indeed, one of the great advances of the 
WFD is related to the measurement of the ecological quality of the water, where the physical-chemical factors are relegated to a second level (those that where basically measured in the former directives) and the biological factors gain more importance. The WFD considers that the biological part is the reflection of the entire ecosystem on which it depends. This point of view is really novel and marks a before and an after in the way of managing the aquatic resources.

\section{Water protection in the Canary Islands}

As in the rest of the European Union, in Spain, the WFD came to cover important legal gaps in relation to both underground and superficial water policies. In the case of coastal superficial waters, until the WFD comes into force, the Spanish legislation had the Law of Coasts. This law, in reference to water quality, only mentions the need of recording the spills and the holder's compromise in doing so without affecting it. The installation of desalination plants is also regulated in the Real Decree 1327/1995.

In Spain, the autonomous regions have competence on the implementation of the WFD. The autonomous region of the Canary Islands (located at $115 \mathrm{~km}$ off the African continent coast, between North parallels $27^{\circ} 38^{\prime}$ and $29^{\circ} 24^{\prime}$ and the West longitude meridians $13^{\circ} 5^{\prime}$ and $18^{\circ} 15^{\prime}$ ) does not have significant fresh water currents, and therefore the waters that are regulated are the subterranean and coastal waters. Thus, the coastal waters studied for the implementation of the WFD are especially important because they represent one of the largest Spanish superficial waters of this type, reaching $4550.44 \mathrm{~km}^{2}$ and depths of up to 100 meters.

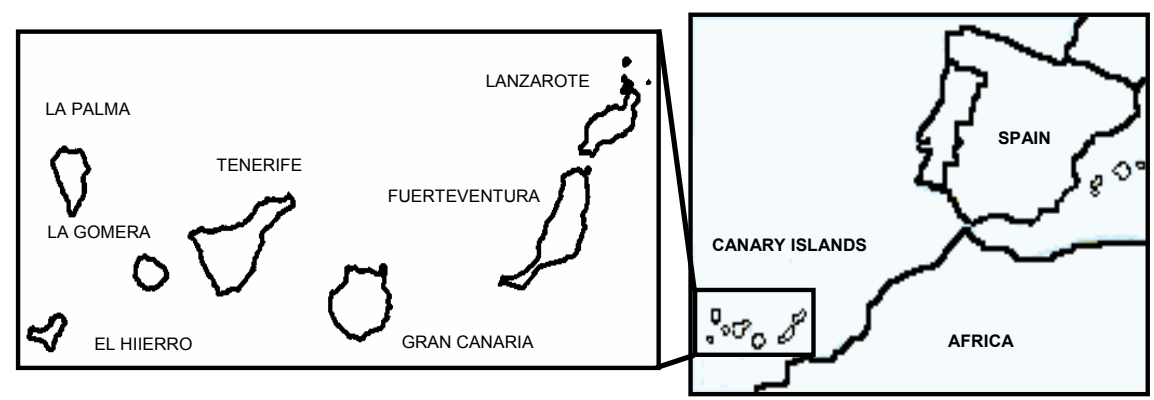

Figure 1: $\quad$ Canary Islands' location map.

Its ecological value has been internationally recognized, declaring it as a Special Sensibility Marine Area, and at national level declaring three marine reserves of fishing interest. At the same time, these waters constitute an important element to sustain the region's main sources of income, which are tourism and fishing. Therefore, the Canary law has contemplated two subjects that acquire great relevance in its territory: the ports (Law 14/2003) and the fishing (Law 17/2003). This last one declares the protection of bottoms with seagrass and, in particular, the Cymodocea nodosa ones. In addition, the 
Government of the Canary Islands has proposed the incorporation of 22 marine spaces to the Nature 2000 Network.

The great problem of canary coastal waters is the degree of anthropogenic pressures to which they are exposed. The abrupt relief of the islands has facilitated the establishment of most of the population in the coast. Also, in these past years the islands have been one of the most important tourist destinations of Europe, due to their sun and beach offer. In this aspect, the political strategy has fundamentally supported the development of this market, before stimulating important industrial activities. Thus, the main entrances of polluting agents are the urban waste waters and the brine spills of the desalination plants.

It is therefore considered that the introduction of the Directive in the Canary Islands has a special interest, not only due to the aspects previously mentioned, but also because of its insular nature and since it is an ultra peripheral region of the European territory.

\section{WFD implementation works in the Canary Islands}

The WFD implementation works carried out until nowadays for the coastal Canary waters, following the established chronogram, are:

- Characterization of the types of coastal water masses (point 1.1. in Annex II of the WFD)

- Identification of the pressures and impact evaluation (points 1.4. and 1.5. in Annex II of the WFD)

- Selection of biological indicators by means of intercalibration exercise (point 1.4. in Annex V of the WFD)

- Design a Monitoring Program for Superficial Waters (point 1.5. in Annex 5 of the WFD).

\subsection{Characterization of the types of coastal water masses}

The first task associated to the implementation of the WFD for coastal waters, carried out during the year 2004, was establishing the limits and their tipification, according to article 5 and following the criteria of Annex II. In the Canary Islands it was made following System B proposed in the WFD, considering the variables "exposure to the surge" (exposed or protected) and "depth" ( $<50 \mathrm{~m}$ are shallow waters and $>50 \mathrm{~m}$ are deep waters), including an additional variable, corresponding to the "degree of pressure supported by the coast", which allowed to separate adjacent water masses of the same typology (table 2). Only oceanographic criteria were considered because otherwise, there would have been an unmanageable number of water masses [2].

Finally, there were five types of water and 32 masses of coastal water defined in the Canary archipelago, which must be treated individually due to the geographic fragmentation of the territory, where the interior waters are delimited for each island. The types of water are represented in all the islands and the water masses have sizes from $1596 \mathrm{~km}^{2}$ to $1.33 \mathrm{~km}^{2}$. It is possible to point out that, in a 
preliminary way, five truly modified masses of waters have been defined, corresponding to ports of state interest.

Table 1: Types of Canary coastal waters.

\begin{tabular}{|c|c|c|c|c|c|}
\hline VARIABLES & TYPE I & TYPE II & TYPE III & TYPE IV & TYPE V \\
\hline Exposure to surge & Exposed & Protected & Protected & Exposed & Protected \\
\hline Depth & Shallow & Shallow & Deep & Shallow & Shallow \\
\hline Presence of pressure & No & No & No & Yes & Yes \\
\hline
\end{tabular}

\subsection{Identification of significant pressures}

The anthropogenic pressures on the coast are the main sources of coastal water pollution. For this reason, the WFD considers vitally important the elaboration of inventories of the activities exerted on the coast. These activities, susceptible of generating a remarkable impact on the water masses, can imply the risk of not reaching the established environmental objectives in the WFD. The classification of the pressures was made according to the following thresholds:

Table 2: $\quad$ Thresholds to define significant pressures.

\begin{tabular}{|c|c|c|}
\hline Pressure & Type & Threshold/criteria \\
\hline \multirow{4}{*}{ Concrete } & Urban spills & $500 \mathrm{~m}^{3} / \mathrm{d}$ \\
\cline { 2 - 3 } & $\begin{array}{c}\text { Biodegradable industrial } \\
\text { spills }\end{array}$ & $500 \mathrm{~m}^{3} / \mathrm{d}$ \\
\cline { 2 - 3 } & $\begin{array}{c}\text { Industrial spills of IPPC } \\
\text { activities }\end{array}$ & All \\
\cline { 2 - 3 } & $\begin{array}{c}\text { Spills with dangerous } \\
\text { substances }\end{array}$ & See list I, II Preferential and priority \\
\cline { 2 - 3 } & Brine spills & $2000 \mathrm{~m}^{3} / \mathrm{d}$ \\
\cline { 2 - 3 } & Thermal spills & $40,000 \mathrm{~m}^{3} / \mathrm{d}$ \\
\hline \multirow{4}{*}{ Diffuse } & Ports & $\begin{array}{c}\text { Maritime traffic, transported substances } \\
\text { and services offered by the port }\end{array}$ \\
\cline { 2 - 3 } & $\begin{array}{c}\text { Aquaculture exploitations in } \\
\text { open ocean }\end{array}$ & \begin{tabular}{c} 
Production over 1000 tons/year \\
\hline
\end{tabular} \\
\hline
\end{tabular}

Finally, a total of 57 pressures were determined, which may be classified in 5 types, having the following relative importance:

Waste water treatment plants $>$ desalination plants $>$ ports $>$

thermal power stations $>$ others 


\subsection{Choice of biological indicators}

One of the WFD's key objectives is to obtain at least a good ecological quality of the superficial water masses. This state is determined from the measurement of a series of biological indicators, both physical-chemical and hydro-morphologic, where the biological ones are considered the most important due to their quality of reflecting the state of the rest of the ecosystem's components.

Following the proceedings of the European Union, the Canary Islands belong to the Atlantic eco-region, with countries like Portugal, France, United Kingdom, Ireland, Belgium, Holland, Denmark, Norway, Sweden and other Spanish regions. Each eco-region must choose common indicators, parameters and methodologies, in order to make its results comparable. This work is made using the intercalibration exercise, for which Geographical Intercalibration Groups (GIG) were created for each water class. The GIG of the Northeast Atlantic (NEA), in which the Canary Islands participate with their coastal waters, has already organized three meetings to choose the biological indicators presented in table 3 .

Table 3: Biological indicators agreed in the intercalibration exercise by the Geographical Intercalibration Group of the NEA.

\begin{tabular}{|c|c|c|}
\hline Indicator & Parameter & Data treatment \\
\hline $\begin{array}{c}\text { Composition } \\
\text { and abundance } \\
\text { of } \\
\text { phytoplankton }\end{array}$ & $\begin{array}{c}\text { Phytoplankton biomass } \\
\text { measured from chlorophyll a } \\
\text { concentration }\end{array}$ & Percentile 90 and medium \\
\cline { 2 - 3 } & $\begin{array}{c}\text { Total number of cells of the } \\
\text { microphytoplankton and } \\
\text { nanoplankton }\end{array}$ & $\begin{array}{c}\text { Percentage of samples that } \\
\text { surpass a determined threshold }\end{array}$ \\
\hline $\begin{array}{c}\text { Composition } \\
\text { and abundance } \\
\text { of other type of } \\
\text { aquatic flora }\end{array}$ & Macroalgae & Presence/absence of species \\
\cline { 2 - 4 } & Marine phanerogam & $\begin{array}{c}\text { Distribution limits, relation of } \\
\text { these limits with water turbidity } \\
\text { and quantification of nitrogen } \\
\text { contents in the environment }\end{array}$ \\
\hline $\begin{array}{c}\text { Invertebrate } \\
\text { diversity }\end{array}$ & $\begin{array}{c}\text { Diversity of benthonic } \\
\text { invertebrates }\end{array}$ & $\begin{array}{c}\text { Relation between taxons sensible } \\
\text { and tolerant to pollution }\end{array}$ \\
\hline
\end{tabular}

\subsection{Monitoring program}

The monitoring program is carried out to control the quality of superficial waters, in order to obtain a coherent and complete general vision of the state of waters (article 8 of the WFD). A series of sampling stations are established and the selected indicators are analyzed with a certain frequency, evaluating the ecological quality. The objective is to try to make the monitoring and the ecological evaluation in a simple way [3]. 
In the Canary Islands, the monitoring program has been designed so that it is technically and economically viable. In this respect, the number of defined points includes all the water masses, at different distances from the coast and diverse depths:

In shallow waters, the transects have been established in the following way:

- A transect perpendicular to coast every $17.5 \mathrm{~km}$ of coastal longitude, this initial segmentation has given as a result the achievement of 84 transects.

- For each transect, a sampling point has been established in the levels $5,-15,-30,-50$, a total of 4 sampling points per transect.

In deep waters transects have been established in the following way:

- In a general way, a transect perpendicular to the coast has been established, coinciding with the layouts for shallow waters every $35 \mathrm{~km}$ of coastal longitude, existing exceptions in some islands.

- For each of these transects a sampling point of 1000, 3000, $5000 \mathrm{y}$ 10,000 meters has been established, counted from the interior limit of the deep waters (level -50 meters).

Finally, the sampling points defined for the monitoring program add 336 in shallow waters and 64 in deep waters (figure 3), in which samples will be taken from the surface, from the sea bottom, and at the middle of the water column in deep areas. In each sample, an average of 20 parameters will be analyzed. To this it is necessary to add the control of the significant pressures with their corresponding indicators.

Due to its insular condition, the water surface to be sampled is very extensive, thus it was determined to sample a not too elevated number of points so that the costs were not excessive, and enough to include the variability of all the water masses. However, as already mentioned, enough pressures exist that are not registered and that can be affecting the quality of some water mass. Therefore, in case these pressures do not have a sampling point nearby, they may be unnoticed and continue affecting the quality of the water mass, since they would have surpassed the first "sieve" of the monitoring which is the monitoring control (or preliminary examination, if it is the first time it is carried out).

\section{Problems of the WFD application in the Canary Islands}

Below, various problems that have arisen during the WFD implantation works in the Canary archipelago are put forward:

- In order to make a suitable pressure monitoring, as established by the WFD, it is necessary to have updated data. In the Canary Islands there are information gaps on the real pressures that affect the coast, which to great extent makes the evaluation of the chemical quality of water masses difficult.

- The ecological evaluation of the water masses must be obtained from the EQR. This index is obtained from the quotient between the real value of each indicator and its reference value. In the Canary Islands, the reference conditions have not yet been established due to lack of data and regular studies that allow 
comparison, situation extended to great part of the European regions, where discussion and definition of procedures is urgently needed [4].

- In spite of the Canary Island's participation in the meetings maintained by GIG NEA, a main problem exists in this community derived from its geographic location. This archipelago has a series of bioclimatic and biogeographical characteristics not comparable with the rest of countries included in its GIG. Until now, the parameters treated for each of the indicators are not adequate to evaluate the water quality in the Canary Islands. Below appear those whose measurement does not adjust to the necessities of the archipelago:

A. Benthos: The established indexes are AMBI (from AZTI), Shannon and the resources. For the application of index AMBI, agreed by most of the countries, it is necessary to reach the species level [5]. However, in the Canary Islands its application is difficult, since only the family level has been achieved.

B. Microalgae: the index set to evaluate the diversity of the communities of red, green and brown seaweed is the $\mathrm{R} / \mathrm{V}$, (UK Macroalgae tools paper). In the Canary Islands, differences are found as far as species and their roll in the ecosystem, since species that can appear as dominant in the coasts of the North Atlantic, are relegated to a secondary roll in warmer coasts, appearing as dominant in these areas other species. In addition, the intertidal must be differentiated from the subtidal.

C. Angiosperms: the parameter established is the analysis of the deep prairie's depth limits, comparing them with nitrogen concentration and Secchi's turbidity data. In the Canary Islands, calculation of the biological index defined by the group of the United Kingdom is possible, but it is not yet known if this index defines correctly the ecological state of the water masses described in the Canary Islands, since this state has still not been defined, due to the region's lack of reference values. It is obvious that the phanerogam species that make up the marine prairies in the Nordic regions are different, thus making the comparison difficult. Therefore it is necessary to be able to establish density and cover comparatives with other countries in these latitudes and with similar geographic characteristics.

As previously mentioned, the ecological quality of waters is evaluated to a great extent using the biological indicators. For that reason, the discrepancies in the selection of these indicators in the case of canary coastal waters, can limit the comparison of the ecological quality results with some of the countries pertaining to the same Geographic Intercalibration Group.

\section{Conclusions}

The WFD is a complex text, since it should adapt to the different idiosyncrasies of all the State Members of the European Union, thus the difficulty of its implementation. However, in the Canary Islands, the different works established to date have been carried out in an efficient manner and fit to the timetable. 
The Directive's application can derive in an improvement of the Canary superficial waters. Nevertheless, the problems put forward until now in the intercalibration exercise, make the definition of a new eco-region necessary for the correct evaluation of the ecological quality of canary coastal waters [6].

In any case, the objective to reach a good quality for all the water masses is questionable, considering the high costs that it entails and the degree of fulfilment of the state members [7]. Everything depends on the existence of an absolute coordination when working with the rest of the European regions. If all the difficulties set forward until now are overcome, we will be on the right track to adequately protect one of the most valuable resources of the future: the water.

\section{References}

[1] Heiskanen A.-S., van de Bund, W., Cardoso, A.C., Towards a good ecological status of surface waters in Europe- interpretation and harmonisation of the concept, Water Science and Technology 49, pp. 169177. 2004.

[2] Borja A., Franco, J., Valencia, V., Bald, J., Muxika, I., Belzunc, J., Solaun, O., Implementation of the European water framework directive from the Basque Country (northern Spain): a methodological approach, Marine Pollution Bulletin 48, pp. 209-218. 2004.

[3] Borja A., H. Heinrich, Implementing the European Water Framework Directive: The debate continues. Marine Pollution Bulletin 50, pp. 486-488. 2005.

[4] Andersen, J.H., Conley, D.J., Hedal, S., Palaeoecology, reference conditions and classification of ecological status: the EU Water Framework Directive in practice, Marine Pollution Bulletin 49, pp. 283-290. 2004.

[5] Borja A., The biotic indices and the Water Framework Directive: the required consensus in the new benthic monitoring tools, Marine Pollution Bulletin 48, pp. 405-408. 2004.

[6] Borja A., The European Water Framework Directive: a challenge for the nearshore, coastal and continental shelf research, Continental Shelf Research 25, pp. 1768-1783. 2005.

[7] Kallis G., Butler, D., The EU water framework directive: measures and implications, Water Policy 3, pp. 125-142. 2001. 